\title{
Hormones and monensin use to improve pregnancy rates in grazing lactating beef cows in the semiarid region of Argentina
}

\section{Pablo Sebastián Reineri ${ }^{1,2}$, Mónica Belén Piccardi ${ }^{3}$, José Ignácio Arroquy $\mathbf{J}^{1,2}$, Arnaldo Fumagalli ${ }^{1,2}$, María Sumampa Coria ${ }^{3}$, Olegario Hernández ${ }^{1}$, Gabriel Bó ${ }^{4,5}$, Gustavo Adolfo Palma ${ }^{2,3,6}$}

\author{
${ }^{1}$ National Institute of Agricultural Technology, EEA-Santiago del Estero, Santiago del Estero, CP 4200, Argentina. \\ ${ }^{2}$ Faculty of Agronomy and Agribusiness, National University of Santiago del Estero (UNSE), Santiago del Estero, CP 4200, \\ Argentina. \\ ${ }^{3}$ Animal Production Laboratory, Institute of Bionanotechnology of the NOA (INBIONATEC), Santiago del Estero, G4206XCP, \\ Argentina. \\ ${ }^{4}$ Faculty of Agricultural Sciences, National University of Córdoba (UNC), Córdoba Capital, CP 5001, Argentina. \\ ${ }^{5}$ Institute of Animal Reproduction Córdoba, Paraje Pozo del Tigre, Córdoba, CP 5145, Argentina.
}

\begin{abstract}
The objectives of this study were 1) to determine the effect of monensin treatment, alone or combined with a hormonal estrus synchronization treatment, on the pregnancy rate of lactating beef cows, and 2) to evaluate the effect of monensin capsule administration on ruminal metabolism in steers. In experiment 1 , ninety-four cows were selected from a 300 cow herd. The experimental design used was a $2 \times 2$ factorial with the administration of monensin capsule as first factor $(\mathrm{M} 1=$ with monensin vs. $\mathrm{M} 0=$ without monensin) and hormonal treatment as second factor (H1 = with hormonal treatment vs. $\mathrm{HO}=$ no hormonal treatment). Thirty-eight days before the beginning of the breeding season, cows were randomly assigned to the first factor, and thirty days later to the second factor, resulting in four treatments: $\mathrm{M} 1 \mathrm{H} 0, \mathrm{M} 1 \mathrm{H} 1, \mathrm{MOH} 0$ and M0H1. Cow were exposed to bull (bull/cow ratio 1:20) from day 0 (day $0=$ start of the breeding season and 38 days after monensin capsule administration) to day 50 . Pregnancy diagnosis was performed at 30, 60 and 80 days after start breeding season by ultrasonography. In experiment 2, eight ruminally cannulated crossbred beef steers were randomly assigned to two treatments (M1 and M0). To determine proportion of volatile fatty acids (VFA), ruminal fluid samples were taken on days 0,40 and 77 of the experimental period, at 0,4 and $12 \mathrm{~h}$ after grazing. In experiment 1 , treatments whit monensin did not improve pregnancy rate $(\mathrm{P}=0.95)$, however, hormonal treatment resulted in grater pregnancy rates $(P=0.03)$. In experiment 2 , the proportion of VFA in ruminal fluid of steers was significantly different between treatments. The highest proportion of propionate was found in ruminal fluid from M1 treatment at $12 \mathrm{~h}$ after grazing $(\mathrm{P}=0.04)$. In conclusion, the treatment with monensin increased the proportion of propionate. The result might suggest that energy balance was improved in steers, without improvement in cow's pregnancy rates. Treatment with monensin alone did not improve pregnancy rate, nor did treatment with monensin enhance the pregnancy rate when a hormonal synchronisation treatment was given. Nevertheless, the use of a hormonal treatment increased pregnancy rate, suggesting that it could be used as a suitable tool to enhance the productivity in cows with marginal body condition score.
\end{abstract}

Keywords: hormone, monensin, pregnancy rate, volatile fatty acids.

\section{Introduction}

Anestrus at the beginning of the breeding season is often the main constraint in pregnancy levels of breeding herds. Low forage availability, low body condition score (BCS) at calving and increased requirements for lactation, are the main nutritional causes that directly influence the productivity of the herd. These factors generate a negative energy balance, determining postpartum anestrus (Diskin et al., 2003; Hess et al., 2005; Diskin and Kenny, 2016). Also the inadequate glucose availability affects negatively gonadotropin-releasing hormone $(\mathrm{GnRH})$ and the luteinizing hormone ( $\mathrm{LH}$ ) release (Wettemann et al., 2003; Hess et al., 2005), essential hormones for resumption of cyclcicity. The main source of energy in ruminants is obtained from volatile fatty acids (VFA), particularly propionic acid (Dicostanzo et al., 1999). Cattle grazing native pasture fed low quality diets, with higher levels of acetate and lower proportion of propionate (Hawkins et al., 2000). In these systems, the use of modifiers to manipulate rumen fermentation such as monensin, could stimulate the production of gluconeogenic compounds, changing the proportion of VFA; mainly the proportion of acetate-propionate, towards a higher proportion of propionate, increasing the synthesis of hepatic glucose and improving the energy balance (Ipharraguerre and Clark, 2003). The increase in the proportion of ruminal propionic acid and the availability of glucose, could improve the partition of nutrients towards the hypothalamic-pituitary-gonadal axis, reversing the postpartum anestrus situation (Diskin et al., 2003; Hess et al., 2005). In addition, some authors reported that monensin supplementation decrease time to the first postpartum ovulation in Holstein cows, and increase follicle size at 55 days postpartum in Nellore cows (Tallam et al., 2003, Matos et al., 2004). Many studies have been carried out in order to evaluate the use of hormonal treatments to reduce the calving-conception interval (Bó et al., 2003; Baruselli et al., 2012). However, few studies have evaluated the concomitant effect of reproductive hormonal treatments in conjunction with ruminal 
fermentation modifiers. Therefore, the aims of this study were to evaluate the effect of monensin treatment, alone or combined with a hormonal estrus synchronization treatment, on the pregnancy rate of lactating beef cows and to evaluate the effect of the monensin capsule on ruminal metabolism in steers.

\section{Materials and Methods}

The experiments were carried out over a period of 118 days, on a commercial herd, located in northwest Argentina (S27 17'34, 3"-W062 ${ }^{\circ}$ 15'14, 1") during December to March. During the experimental period (from day -38 to 80 ), the precipitation was 825 millimeter and the average temperature was $26.5^{\circ} \mathrm{C}$. The mean maximum and minimum temperature were $32.5^{\circ} \mathrm{C}$ and $20.5^{\circ} \mathrm{C}$, respectively, and the average maximum temperature of the days when the animals were expected to be in estrus after synchronization, (day 0 to 5), was $36.2^{\circ} \mathrm{C}$. The animals used in the present study had been grazed in the same paddock on Guinea grass (Megathyrsus maximus, cV. Gatton panic) throughout the experimental period. With an initial forage availability of $5763 \pm 1359 \mathrm{~kg}$ DM/ha (60\% stem, 20\% green leaf, $2 \%$ inflorescence and $18 \%$ dead leaf and weeds). Animal handling and experimental procedures were in accordance to institutional protocols for Experimental Animal Care and Use approved by the National Institute of Agricultural Technology (Instituto Nacional de Tecnología Agropecuaria - INTA, 2013).

\section{Experiment 1}

Thirty-eight days before the breeding season, crossbreed Zebu (Brangus x Braford) multiparous cows $(n=94)$ with lactating calves from 3 to 4 weeks of age were selected from a herd of 300 cows (Fig. 1). The selection criteria were based on the absence of corpus luteum, diagnosed by ultrasonography and body condition score (BCS) of $3.84 \pm 0.04$, (mean \pm standard error of the mean; SEM). The BCS was evaluated by optical observation in day -38, 0 and 80 , using the score range $1-9,1=$ emaciated and $9=$ obese (Richards et al., 1989).
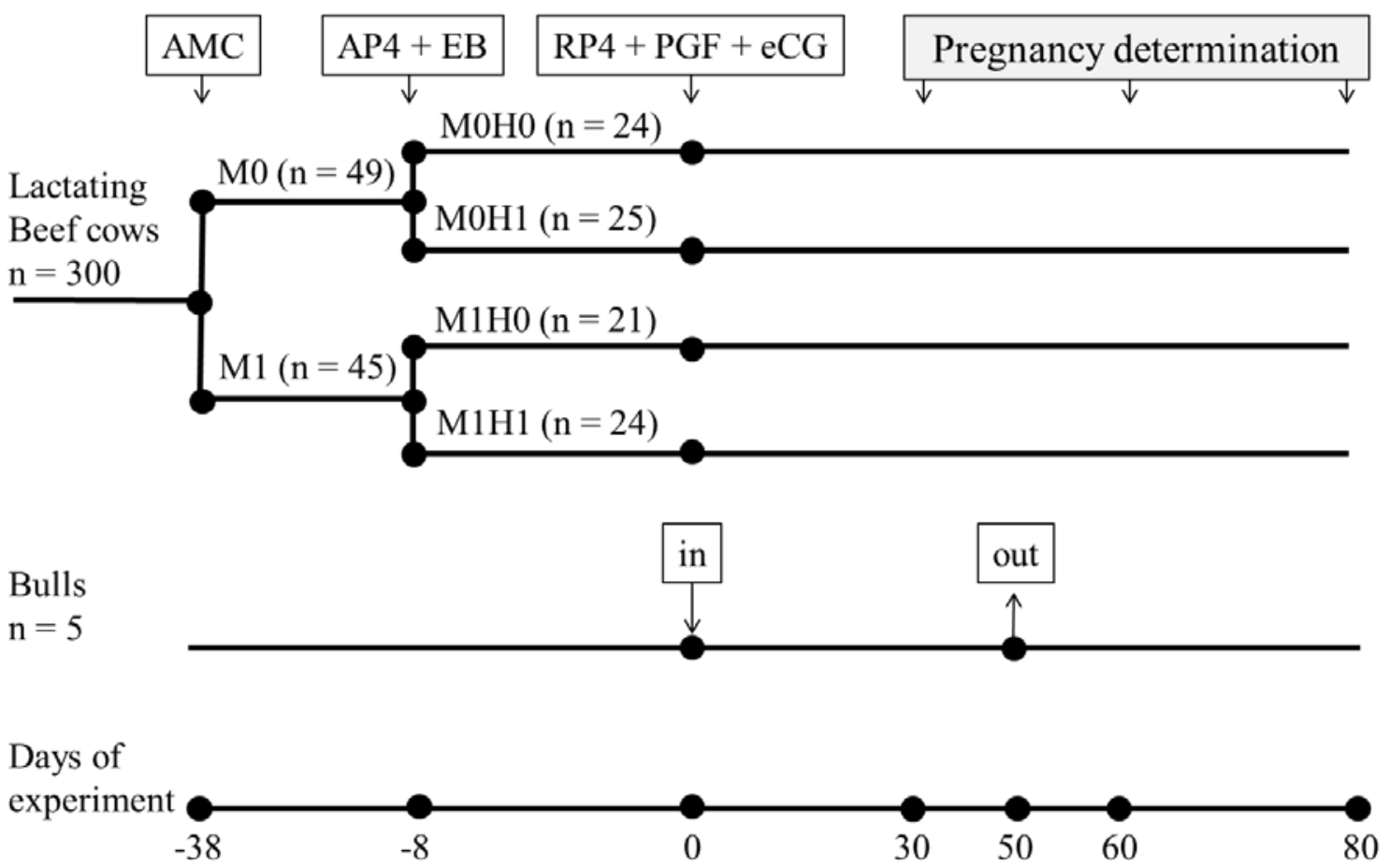

Figure 1. Protocol experiment 1. The experiments were carried out over a period of 118 days. Lactating beef cows were randomly assigned to one of four groups. Ninety-four cows were selected from a 300 cow's herd. The experimental design used was a 2 × 2 factorial with monensin administration as first factor $(\mathrm{M} 1=$ with monensin $v s$. $\mathrm{M0}=$ without monensin) and hormonal treatment as second factor $(\mathrm{H} 1=$ with hormonal treatment vs. H0 = no hormonal treatment). Thirty-eight days before the beginning of the breeding season, the cows were randomly assigned to the first factor, and thirty days later to the second factor, resulting in four treatments: M1H0, M1H1, $\mathrm{MOHO}$ and $\mathrm{MOH} 1$. Bulls were exposed to cows from day 0 to 50 (bull/cow ratio 1:20) and confirmation of pregnancy was performed at 30, 60 and 80 days after start breeding season by ultrasonography. AMC: administration of monensin capsule; AP4 + EB: intravaginal application of progesterone release device $(0,5 \mathrm{~g}$ Progesterone, DIB, Syntex, Argentina) for 8 days, plus $2 \mathrm{mg}$ of estradiol benzoate (Gonadiol, Syntex, Argentina) administrated intramuscularly; RP4 + PGF + eCG: progesterone release device was removed (start of natural service), and intramuscularly were injected $0.15 \mathrm{~g}$ of D (+) cloprostenol (PGF, Syntex, Argentina) and 400 IU of equine chorionic gonadotropin (Novormon Syntex, Argentina). 
Cows were randomly assigned to two treatments: M1 treatment $(\mathrm{n}=45)$, with intra-ruminal slow release monensin capsules administered, each capsule containing $32 \mathrm{~g}$ of crystalline monensin (Rumensin ${ }^{\circledR}$ Elanco Animal Health, Argentina); and M0 (n = 49) without monensin capsule administered. Thirty days later (day -8), both groups were assign to a second treatment factor (hormone administration) in a 2 x 2 factorial arrangement within a completely randomized design. The $\mathrm{H} 1$ group received an intravaginal progesterone releasing device containing $0.5 \mathrm{~g}$ of progesterone (DIB, Syntex, Argentina) for 8 days, plus $2 \mathrm{mg}$ of estradiol benzoate (Gonadiol, Syntex, Argentina) administered intramuscularly. On day 0 (breeding season), DIB inserts were removed and $0.15 \mathrm{~g}$ of D (+) cloprostenol (PGF, Syntex, Argentina) and 400 IU of equine chorionic gonadotropin (Novormon Syntex, Argentina) were administered intramuscularly. Group $\mathrm{HO}$ did not receive any hormonal treatment.

The ninety-four cows were allocated to each treatment and the factorial combination was as follows: M0H0 (n = 24), M1H0 (n = 21), M0H1 ( $\mathrm{n}=25)$ and M1H1 (n = 24).

The bulls used in this study for service were previously evaluated and approved by sanitary, morphological and reproductive standards, in a proportion of bulls to cows of 1:20. Cows were exposed to bulls from day 0 to 50 (Fig. 1). Cows were evaluated for pregnancy and embryonic losses by ultrasonography at 30, 60 and 80 day after start breeding season (Fig. 1), using the ultrasound CHISON 500VET with a $5.0 \mathrm{MHz}$ linear transducer, (Chison Medical Imaging Co., Ltd., Wuxi, China).Positive diagnosis of pregnancy was determined as presence of an embryo or foetus with a visible heartbeat and, at later stages visible foetal movements, total conceptus size, compatible with stage of gestation, and the presence of clear amniotic fluid (Kastelic et al., 1988). Embryonic loss or early foetal death was defined as the absence of a viable embryo or foetus on a given day that had been present at the previous examination by ultrasound (Silke et al., 2002).

\section{Experiment 2}

Thirty-eight days before the breeding season, eight ruminally cannulated crossbred beef steers, four treated with of intra-ruminal slow release monensin capsules (M1) and four without monensin capsule (M0) were used (Fig. 2). The steers group M1 received a monensin capsule containing $32 \mathrm{~g}$ of crystalline monensin (Rumensin ${ }^{\circledR}$ Elanco Animal Health, Argentina). Ruminal fluid samples were taken through the fistulas on days 0 (day $0=$ start of the breeding season and 38 days after monensin capsule administered), 40 and 77 . Samples were taken at three times during the sampling day, before leaving to graze (hour 0 ), and 4 and $12 \mathrm{~h}$ after the start of grazing (Fig. 2). Twelve hours before each sampling day, the steers were collected from the pasture. At dawn the next day, before the grazing activity, ruminal fluid samples were taken through ruminal fistulas (hour 0), then the steers were allowed to graze for $4 \mathrm{~h}$ and then were collected from the pasture to take the second daily sample (hour 4), after sampling they were allowed to graze another four hours to take the last sampling at hour 12 after the start of grazing. For VFA analysis, $8 \mathrm{ml}$ of ruminal liquid were diluted in $2 \mathrm{ml}$ of metaphosphoric acid $25 \%$ $(\mathrm{w} / \mathrm{v})$, immediately placed at $4^{\circ} \mathrm{C}$, and then frozen at $20^{\circ} \mathrm{C}$, to be subsequently analyzed (Olson, 1991). Samples were thawed at room temperature and centrifuged at $17,000 \mathrm{xg}$ for $15 \mathrm{~min}$. The VFA content was analyzed by gas chromatography using a flame ionization detector (Konik HRGC-3000C) fitted with a capillary column Zebron ZB-FFAP (15 mx di 0.32, 0.25 $\mathrm{m}$; Phenomenex). Temperature was set at $100^{\circ} \mathrm{C}$ for 3 $\mathrm{min}$, with increase of $8^{\circ} \mathrm{C} / \mathrm{min}$ from 100 to $230^{\circ} \mathrm{C}$. The carrier gas was $\mathrm{N} 2$ at $1.66 \mathrm{ml} / \mathrm{min}$. Split ratio: 20:1.

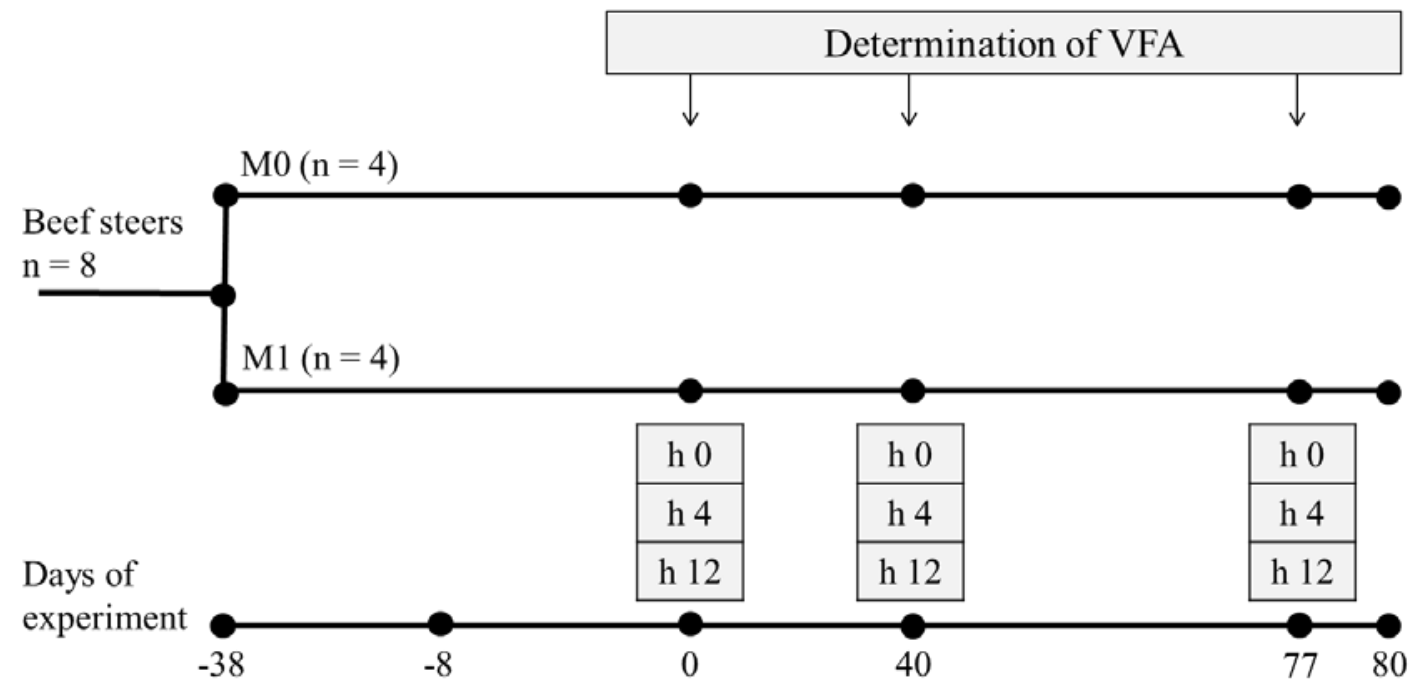

Figure 2. Protocol experiment 2. Eight ruminally cannulated crossbred beef steers, four dosed with monensin (M1) and four without monensin (M0), were used. Ruminal fluid samples were taken through the fistulas on days 0,40 and 77. Samples were taken at three times during the sampling day, before leaving to graze (hour 0 ), and 4 and $12 \mathrm{~h}$ after the start of grazing. VFA: volatile fatty acids; h: hour. 
Reineri et al. Treatments to improve pregnancy rate.

\section{Statistical analysis}

Pregnancy rate cow's data was analyzed as a completely randomized design with a $2 \times 2$ factorial arrangement and data from BCS in cows and steers ruminal fermentation profile were analyzed as a completely randomized design. To compare the percentage of pregnant animals related to treatments among days of breeding, survival analysis of Kaplan and Meier was used. The difference of the curves given by the treatments was compared using the Log-Rank statistic (Kaplan and Meier, 1958). A high value of LogRank corresponds to a small P-value. BCS data from cows of experiment 1 and VFA data from steers of experiment 2 were analyzed as repeated measures with linear mixed-effects model procedure through the $\mathrm{R}$ interface with Infostat software (Di Rienzo et al., 2017).

The model used for analysis of variance was:

$\mathrm{Y}_{\mathrm{ijkl}}=\mu+\mathrm{M}_{\mathrm{i}}+\mathrm{D}_{\mathrm{j}}+\mathrm{A}_{\mathrm{k}}+\mathrm{t}_{\mathrm{l}}+(\mathrm{MD})_{\mathrm{ij}}+(\mathrm{Mt})_{\mathrm{il}}+(\mathrm{Dt})_{\mathrm{jl}}$ $+(\mathrm{MDt})_{\mathrm{ijl}}+\varepsilon_{\mathrm{ij}}$

Where $Y_{\mathrm{ijkl}}$ is the dependent variable (BCS or VFA), $\mu$ is the overall mean, $M_{i}$ is a fixed effect of monensin administration $i, D_{j}$ is a fixed effect of day $j$, $A_{k}$ is the random effect of animal $k, t_{l}$ is the fixed effect of hour $1,(M D)_{i j}$ is the fixed effect of interaction between monensin administration $\mathrm{i}$ and day $\mathrm{j},(\mathrm{Mt})_{\mathrm{ik}}$ is the fixed effect of interaction between monensin treatment $\mathrm{j}$ with time $\mathrm{k},(\mathrm{Dt})_{\mathrm{jl}}$ is the fixed effect of interaction between day $\mathrm{j}$ and time $\mathrm{l},(\mathrm{MDt})_{\mathrm{ijl}}$ is the fixed effect of interaction among monensin administration $i$, day $\mathrm{j}$ and time $\mathrm{l}$, and $\varepsilon_{\mathrm{ijkl}}$ is the random error.

In all statistical analyzes used, the level of significance was set ak P0.05. The trend was considered when the $\mathrm{P}$ value was between 0.10 and 0.05 .

\section{Experiment 1}

\section{Results}

Survival curves for pregnancy rate throughout days of service after hormonal and monensin treatments are shown in Fig.3. Survival curves, which indicate the percentage of non-pregnant animals as function of time elapsed from day 0 to $\mathrm{d} 80$ not shows significant differences (Log Rank Test $=4.63, \mathrm{P}=0.20$ ). Pregnancy rates on day 80 were: $46 \%$ (11/24), $48 \%$ (10/21), 68\% (17/25) and 71\% (17/24) for $\mathrm{MOH} 0$, M1H0, M0H1 and M1H1, respectively.

Pregnancy rate was not affected by the interaction between the monensin capsule administration and the hormonal treatment. Therefore, the main effects for monensin and hormonal treatments were evaluated. No difference was observed between M0 and M1 (Log Rank Test = 0.03, P = 0.95; Fig. 3). However, statistical difference was observed between $\mathrm{HO}$ and H1. Pregnancy rate of animals without hormonal treatment (H0) was significantly lower than those with hormonal treatment $(\mathrm{H} 1$; Log Rank Test $=$ $4.59, \mathrm{P}=0.03$, Fig. 3 ) in survival curves. In addition, in none of the treatments evaluated during the experimental period were embryonic losses observed.

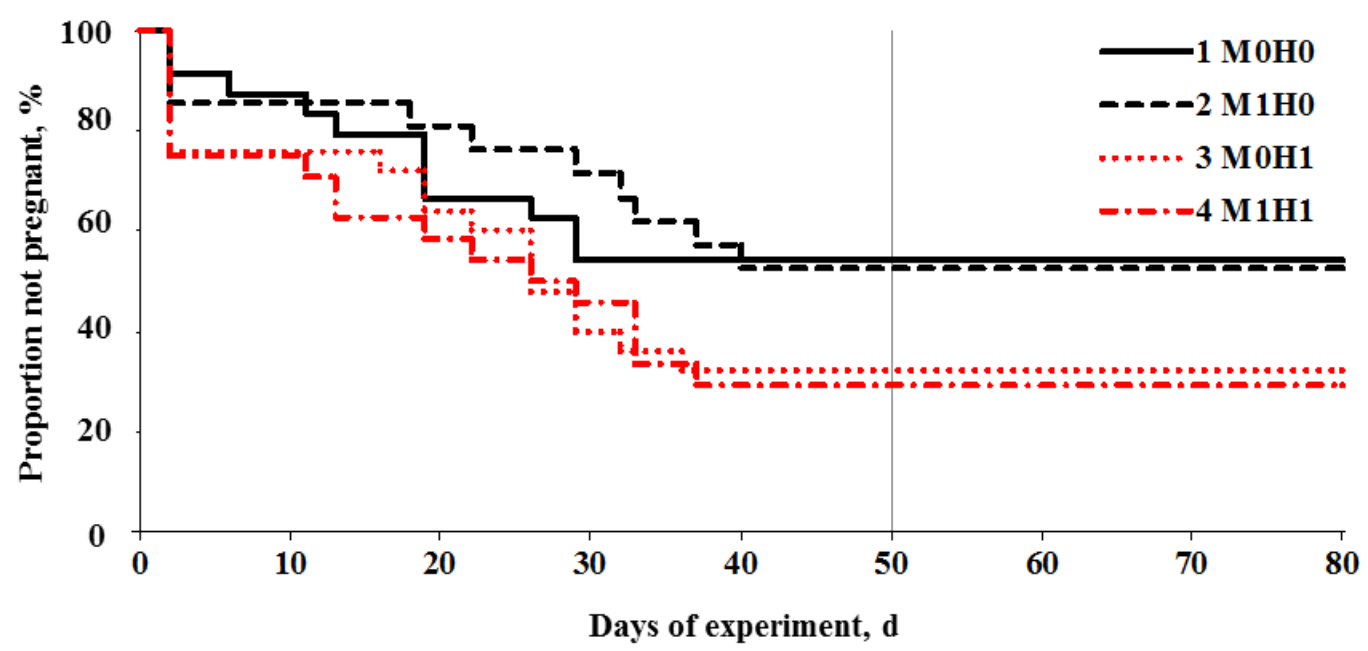

Figure 3. Effect of monensin capsules and hormone treatment on survival curves ( $\mathrm{n}=94$ cows) throughout $\mathrm{d} 0$ to 80 of experiment interval $(\mathrm{P}=0.20) .{ }^{1} \mathrm{M} 0 \mathrm{H} 0=$ Group treatment control (without monensin and without hormones), ${ }^{2} \mathrm{M} 1 \mathrm{H} 0=$ Group treatment with monensin and without hormones, ${ }^{3} \mathrm{M} 0 \mathrm{H} 1$ = Group treatment without monensin and with hormones, ${ }^{4} \mathrm{M} 1 \mathrm{H} 1$ = Group treatment with monensin and with hormones. Period of exposure bulls with cows from day 0 to 50 .

Significant differences were found between days of experiment in body condition score, indicating the higher scores at day 80 , (day $0=4.28 \pm 0.04$ and day $80=5.57 \pm 0.12 ;$ mean \pm SEM; $\mathrm{P}<0.0001)$. Nevertheless, cow BCS not shows statistical differences at the end of breeding season among treatments $(\mathrm{MOHO}=$ $5.63 \pm 0.10, \mathrm{M} 1 \mathrm{H0}=5.36 \pm 0.15, \mathrm{M} 0 \mathrm{H} 1=5.56 \pm 0.10$ and $\mathrm{M} 1 \mathrm{H} 1=5.76 \pm 0.14 ; \mathrm{P}=0.37$ ), or among the main effects $(\mathrm{M} 0=5.6 \pm 0.07, \mathrm{M} 1=5.57 \pm 0.10, \mathrm{P}=0.14 ; \mathrm{H} 0$ $=5.53 \pm 0.08, \mathrm{H} 1=5.65 \pm 0.08, \mathrm{P}=0.76)$.

\section{Experiment 2}

The molar proportion of volatile fatty acids with statistical significant differences was detailed in Fig. 4, data expresses the average for the three sampling days (0, 40 and 77). Acetate proportion was not affected 
by any of the variables studied (treatment $[\mathrm{P}=0.37]$, day $[\mathrm{P}=0.82]$, hour $[\mathrm{P}=0.26]$, interactions between treatment $\mathrm{x}$ day $[\mathrm{P}=0.71]$, treatment $\mathrm{x}$ hour $[\mathrm{P}=0.06]$ and among treatment $\mathrm{x}$ day $\mathrm{x}$ hour $[\mathrm{P}=0.43]$ ), there was a tendency in the interaction between treatment $\mathrm{x}$ hour, resulting in lower level of acetate in M1 group at $12 \mathrm{~h}$ after grazing $(63.55 \pm 2.02$ vs. $68.96 \pm 2.11$ mol per 100 mol [mean $\pm \mathrm{SEM}$ ], $\mathrm{P}=0.06$ ). No statistical differences were observed in proponiante proportion between treatments $(P=0.18)$, days $(P=0.46)$, hours $(P=0.06)$, interactions treatment $x$ day $(P=0.75)$, treatment $x$ day $x$ hour $(P=0.15)$. However, statistical difference was observed in the interaction between treatment $\mathrm{x}$ hour, propionate proportion was modified by the ruminant modulator in steers at $12 \mathrm{~h}$ after grazing, the group with monensin administration (M1) produced higher levels of propionate than M0 (20.05 \pm 1.35 vs. $15.25 \pm 1.41 \mathrm{~mol}$ per 100 mol [mean $\pm \mathrm{SEM}$ ], $\mathrm{P}=0.02$, respectively). The acetate: propionate ratio did not show significant differences between treatment $(P=0.20)$, day $(P=0.94)$, hour $(P=0.20)$, interaction between treatment $x$ day $(\mathrm{P}=0.89)$ and among treatment $\mathrm{x}$ day $\mathrm{x}$ hour $(\mathrm{P}=0.319)$. However, statistical difference was observed in the interaction between treatment $\mathrm{x}$ hour, the acetate: propionate ratio was higher in animals without monensin administration than animals with the ruminant modulator $(4.73 \pm 0.49$ vs. $3.23 \pm 0.47 \mathrm{~mol}$ per $100 \mathrm{~mol}$ [mean $\pm \mathrm{SEM}$ ], $\mathrm{P}=0.04$, respectively).
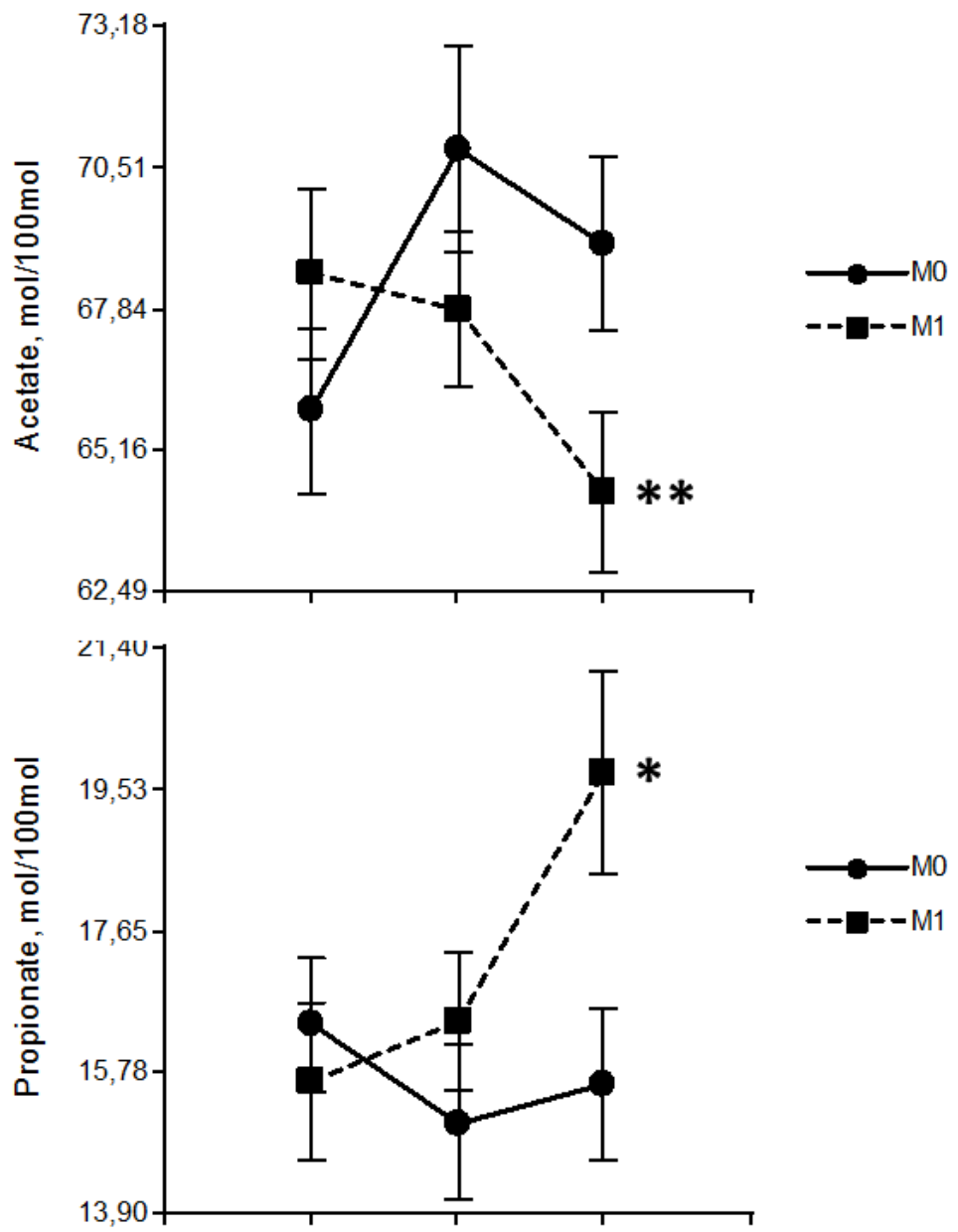

Figure 4. Effect (mean \pm SEM) of treatment $\mathrm{X}$ hour after grazing interaction on the VFA proportion. The proportion of acetate and propionate and the acetate: propionate ratio values presented expresses the average of the three sampling days (0, 40 and 77). Samples were taken at three times during the sampling day (0, 4 and $12 \mathrm{~h}$ after grazing). $\mathrm{M} 1=$ with monensin and $\mathrm{M} 0=$ without monensin. ${ }^{*} \mathrm{P} \leq 0.05$; $* * \mathrm{P}<0.10$ and $>0.05$ ).
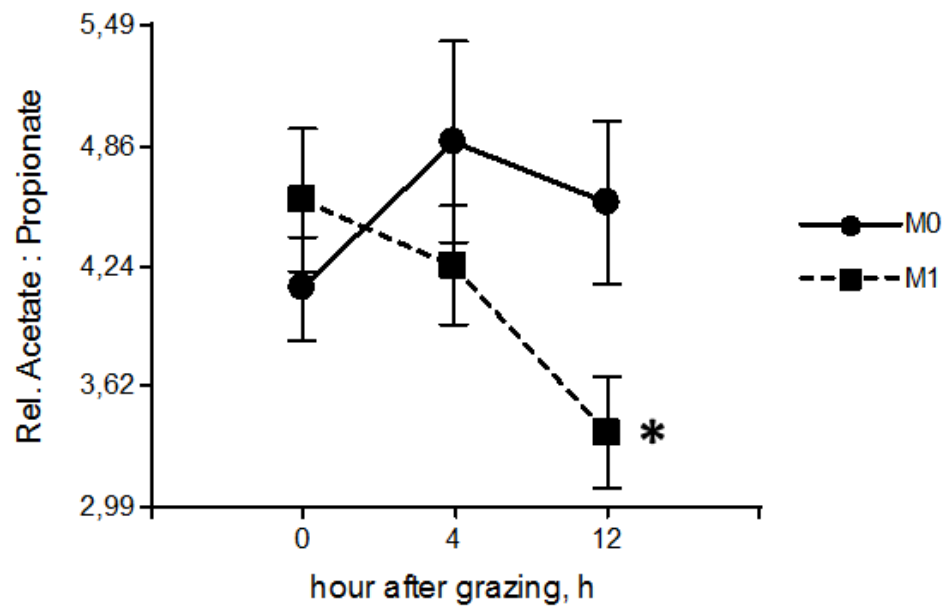


\section{Discussion}

Nutritional management plays a very important role in reproductive programs. Body energy reserve at calving is the most important factor influencing pregnancy rate in beef females. Energy and protein are the nutrients required in the greatest amounts and are the first priority in nutritional programs to optimize reproduction (Bossis et al., 1999; Diskin et al., 2003; Hess et al., 2005; Diskin and Kenny, 2016). Beef females underfed or in poor body condition lack ovarian activity as a result of suppression of pulsatile release of LH under the control of GnRH (Rasby and Funston, 2016). Feeding monensin to grazing beef cows did not affect BCS change in experiment 1 , however differences between days were observed, and founding higher scores on day 80 of the experiment. In previous literature, cows consuming monensin during gestation had decreased forage intake, accompanied by either an improvement (Sexten, 2011) or no change in cow gain (Linneen et al., 2015). Bretschneider et al. (2008) reported an increase in average daily gain of $12.1 \%$ for growing cattle consuming monensin when comparing 46 experiments in a review on the effects of feeding grazing cattle monensin. Perhaps, in this study, monensin simply did not improve energetic efficiency in large enough magnitude to elicit a gain response.

It has been demonstrated that limited metabolic fuel availability, promotes an inadequate production and release of hypothalamic $\mathrm{GnRH}$ and pituitary $\mathrm{LH}$ (Wettemann et al., 2003; Hess et al., 2005). In this sense, low levels of $\mathrm{LH}$, results in low production of androgens and consequently low concentration of estrogen. In this scenario, not pre-ovulatory LH peak is produced, and dominant follicle could suffer atresia, resulting in a new anovulatory follicular wave (Roche et al., 1992). This anestrous situation, in low BCS cows, could be reversed by administration of exogenous hormones, such as estradiol, GnRH, LH and eCG (Bó et al., 2003; Sá Filho et al., 2010b, Baruselli et al., 2012). Furthermore, it has been suggested that exogenous hormonal stimulation is necessary to achieve adequate follicular growth, successful ovulation of competent oocyte, and the subsequent formation of functional corpus luteum able of maintain pregnancy (Bó et al., 2003; Sá Filho et al., 2010a; Baruselli et al., 2012; Núñez-Olivera et al., 2018). Moreover, previous studies showed that an increase in circulating progesterone concentrations during the first week after ovulation effectively stimulates embryo enlargement and interferon- $\tau$ secretion, favoring maintenance of pregnancy. Consequently, high-serum progesterone concentrations during the first 2 weeks of gestation are associated with greater pregnancy rates. Similarly, in the present study, the hormonal treatment could achieve follicular atresia and induce new follicular wave's development at 3-4 days. Also, removing progesterone device and injecting the prostaglandin F2 $\alpha$ (PGF2 $\alpha$ ) plasma progesterone concentration decreases, increasing the LH pulses frequency.

In previous studies, eCG treatment in lactating beef cows in anestrous or with low body condition score, improved follicular growth, produced larger diameter of dominant follicle, increase ovulation (Sá Filho et al., 2010b), or increase progesterone concentrations in the next cycle (Baruselli et al., 2004, 2012). Moreover Núñez-Olivera et al. (2018) demonstrated that eCG on day 14 after artificial insemination at fixed time (FTAI) produces positive effect on serum progesterone concentrations during maternal recognition of gestation in anestrous beef cows. In addition, the eCG treatment in combination with progesterone device elimination at day 14 significantly improved the pregnancy rate compared to the control group without treatment with eCG (NúñezOlivera et al., 2018). Positive effects eCG on reproduction described above can be supported due to the it has the peculiar property of provoking both follicle-stimulating hormone (FSH) and LH activity on follicle (Murphy and Martinuk, 1991) and corpus luteum (Stewart and Allen, 1981) in non-equid species (Murphy, 2012). The biological basis for this dual activity is believed to be the result of promiscuity of the mammalian FSH receptors, imparting the capacity to respond to this equine LH-like hormone (Murphy, 2012).

In the present study, the use of monensin had no effect on the pregnancy rate in beef cow. Similar results were described by other authors (Lean et al., 1994; Hayes et al., 1996; Beckett et al, 1998). However, Tallam et al. (2003) reported that the first postpartum ovulation occurred earlier in cows fed monensin than in the control group in multiparous Holstein cows and Matos et al. (2004) found that monensin increased follicle size at day 54 postpartum, but did not affect ovulation rate of Nellore cows. These differences could be associated with the breed of animals and the type of feeding used in each study.

In experiment 2 monensin capsule increases ruminal propionate proportion (gluconeogenic VFA) in cannulated beef steers grazing, as was suggested by other authors (Ipharraguere and Clark, 2003; Rasby and Funston, 2016). The alteration of acetate to propionate ratio was enhanced by the increase in propionic acid production and decrease of acetic acid production, probably caused by the monensin's ability to modify the ruminal microbial population, benefiting propionic acid producing bacteria (Russell and Strobel, 1989; Bell et al., 2017). The increase in propionate concentrations could be followed by an increase in blood glucose levels, and improved GnRH secretion (Randel, 1990; Duffield et al.,1999). Although ruminal metabolism differences were observed between steers that received monensin supplement and those that did not, it was possibly that propionate levels obtained in cows treated was not enough to affect the pregnancy rate, since the nutritional demands between both categories of animals are different (Fox et al., 1992). There are consistent meta-analysis data evaluating the impact of monensin on lactating dairy cow health and reproduction showing no reproductive benefits of monensin on this animal category (Duffield et al., 2008), nevertheless there is lack of information or studies concerning the effect of fermentation modulators on beef cow reproduction. This 
study demonstrates for first time, that the interaction effect of a ruminal fermentation modulator (monensin) and hormone not produces differences in pregnancy rates, whereas hormone administration alone could increase this rate in beef cows with marginal body condition scores during the reproductive season.

In conclusion, the interaction between hormonal and monensin treatment and monensin alone did not generate significant differences in the pregnancy rate. However, in the present study, the main effect of hormonal treatment with progesterone devices, estradiol and eCG increased pregnancy rate on low BCS cows at the beginning of the breeding season. Monensin treatment increased levels of ruminal propionate which could improve energetic efficiency. The use of hormonal treatments would be a suitable tool to increase the pregnancy rate on lactating cows with poor BCS. Although further experiments are essential in order to corroborate these results. It would also be interesting to include some rumen fermentation modifier (monensin or other ones) to enhance some nutritional factors which may interfere and/or limit the use of hormonal treatments and get better reproductive indices.

\section{Conflicts of interest statement}

There are no conflicts of interest.

\section{Acknowledgments}

We thank the Ortolani and Gonzales Families who provided their facilities and animals for the experiment and in particular their veterinary managers Canepa and Principi. We also thank the National Institute of Agricultural Technology, National University of Santiago del Estero, National University of Cordoba, National Council for Scientific and Technical Research, Animal Reproduction Institute Cordoba, by providing human and instrumental resources to develop and culminate with the experimental work.

\section{References}

Baruselli PS, Reisa EL, Marquesa MO, Nassera LF, Bó GA. 2004. The use of hormonal treatments to improve reproductive performance of anestrous beef cattle in tropical climates. Anim Reprod Sci, 82/83:479486.

Baruselli PS, Sá Filho MF, Ferreira RM, Sales JNS, Gimenes LU, Vieira LM, Mendanha MF, Bó GA. 2012. Manipulation of follicle development to ensure optimal oocyte quality and conception rates in cattle. Reprod Domest Anim, 47:134-141.

Beckett S, Lean I, Dyson R, Tranter W, Wade L. 1998. Effects of monensin on the reproduction, health, and milk production of dairy cows. $J$ Dairy Sci, 81:1563-1573.

Bell NL, Anderson RC, Callaway TR, Franco MO, Sawyer JE, Wickersham TA. 2017. Effect of monensin inclusion on intake, digestion and ruminal fermentation parameters by Bos taurus indicus and Bos taurus taurus steers consuming bermudagrass hay. $J$ Anim Sci, 95:2736-2746.

Bó GA, Baruselli PS, Martínez MF. 2003. Pattern and manipulation of follicular development in Bos indicus cattle. Anim Reprod Sci, 78:307-326.

Bossis I, Wettemann RP, Welty SD, Vizcarra JA, Spicer LJ, Diskin MG. 1999. Nutritionally induced anovulation in beef heifersovarian and endocrine function preceding cessation of ovulation. J Anim Sci, 77:1536-1546.

Bretschneider G, Elizalde JC, Pérez FA. 2008. The effect of feeding antibiotic growth promoters on the performance of beef cattle consuming forage-based diets: a review. Livest Sci, 114:135-149.

Di Rienzo JA, Casanoves F, Balzarini MG, Gonzalez L, Tablada M, Robledo CW. InfoStat versión 2017. Córdoba, Argentina: Grupo InfoStat, FCA, Universidad Nacional de Córdoba. Available on: http://www.infostat.com.ar.

Dicostanzo A, Williams JE, Keisler DH. 1999. Effects of short- or long-term infusions of acetate or propionate on luteinizing hormone, insulin, and metabolite concentrations in beef heifers. J Anim Sci, 77:3050-3056.

Diskin MG, Mackey DR, Roche JF, Sreenan JM. 2003. Effects of nutrition and metabolic status on circulating hormones and ovarian follicle development in cattle. Anim Reprod Sci, 78:345-370.

Diskin MG, Kenny DA. 2016. Managing the reproductive performance of beef cows. Theriogenology, 86:379-387.

Duffield TF, Leslie KE, Sandals D, Lissemore K, McBride BW, Lumsden JH, Dick P, Bagg R. 1999. Effect of a monensin-controlled release capsule on cow health and reproductive performance. J Dairy Sci, 82:2377-2384

Duffield TF, Rabiee AR, Lean IJ. 2008. A metaanalysis of the impact of monensin in lactating dairy cattle. Part 3. Health and reproduction. J Dairy Sci, 91:2328-2341.

Fox DG, Sniffen CJ, O'Connor JD, Russell JB, Van Soest PJ. 1992. A net carbohydrate and protein system for evaluating cattle diets: III. Cattle requirements and diet adequacy. J Anim Sci, 70:3578-3596.

Hawkins DE, Petersen MK, Thomas MG, Sawyer JE, Waterman RC. 2000. Can beef heifers and young postpartum cows be physiologically and nutritionally manipulated to optimize reproductive efficiehicy $J$ Anim Sci, 77:1-10.

Hayes DP, Pfeiffer DU, Williamson NB. 1996. Effect of intraruminal monensin capsules on reproductive performance and milk production of dairy cows fed pasture. J Dairy Sci, 79:1000-1008.

Hess BW, Lake SL, Scholljegerdes EJ, Weston TR, Nayigihugu V, Molle JDC, Moss GE. 2005. Nutritional controls of beef cow reproduction. J Anim Sci, 83:90-106.

Instituto Nacional de Tecnología Agropecuaria. 2013. Guia para cuidado y uso de animales de experimentación, 2013. Available on: http://www.inta.gob.ar/ documentos/ manuales-sobre-cuidado-y-supervisación-y-uso-deanimales.pdf. Accessed on: February 19, 2013.

Ipharraguerre IR, Clark JH. 2003. Usefulness of 
ionophores for lactating dairy cows: a review. Anim Feed Sci Technol, 106:39-57.

Kaplan EL, Meier P. 1958. Nonparametric estimation from incomplete observations. J Am Stat Assoc, 53:457481.

Kastelic JP, Curran S, Pierson RA, Ginther OJ. 1988. Ultrasonic evaluation of the bovine conceptus. Theriogenology, 29:39-54.

Lean IJ, Curtis M, Dyson R, Lowe B. 1994. Effects of sodium monensin on reproductive performance of dairy cattle. I. Effects on conception rates, calving-to-conception intervals, calving-to-heat and milk production in dairy cows. Aust Vet J, 71:273-277.

Linneen SK, McGee AL, Cole JR, Jennings JS, Stein DR, Horn GW, Lalman DL. 2015. Supplementation of monensin and Optimase to beef cows consuming lowquality forage during late gestation and early lactation. $J$ Anim Sci, v93:3076-3083.

Matos MC, Biluca DF, Vasconcelos JL, Wechsler FS. 2004. Effects of monensin supplementation peripartum in metabolic and reproductive parameters in anestrous postpartum Nellore cows. J Anim Sci, 82:67-67.

Murphy BD, Martinuk SD. 1991. Equine chorionic gonadotropin. Endocr Rev, 12:27-44.

Murphy BD. 2012. Equine chorionic gonadotropin: an enigmatic but essential tool. Anim Reprod, 9:223-230.

Núñez-Olivera R, Castro T, Bó GA, Piaggio J, Menchaca A. 2018. Equine chorionic gonadotropin administration after insemination affects luteal function and pregnancy establishment in postpartum anestrous beef cows. Domest Anim Endocrinol, 62:24-31.

Olson K. 1991. Diet sample collection by esophageal fistula and rumen evacuation techniques. J Range Manag, 44:515-519.

Randel RD. 1990. Nutrition and postpartum rebreeding in cattle. J Anim Sci, 68:853-862.

Rasby RJ, Funston RN. 2016. Invited review: Nutrition and management of cows: Supplementation and feed additives. Prof Anim Sci,, 32:135-144.
Richards MW, Wettemann RP, Schoenemann HM. 1989. Nutritional anestrus in beef cows: body weight change, body condition, luteinizing hormone in serum and ovarian activity. J Anim Sci, 67:1520-1526.

Roche JF, Crow MA, Bolandb MP. 1992. Postpartum anoestrus in dairy and beef cows. Anim Reprod Sci, 28:371-378.

Russell JB, Strobel HJ. 1989. Minireview effect of lonophores. Appl Environ Microbiol, 55:1-6.

Sá Filho MF, Crespilho AM, Santos JEP, Perry GA, Baruselli PS. 2010a. Ovarian follicle diameter at timed insemination and estrous response influence likelihood of ovulation and pregnancy after estrous synchronization with progesterone or progestin-based protocols in suckled Bos indicus cows. Anim Reprod Sci, 120:23-30.

Sá Filho MF, Torres-Júnior JRS, Penteado L, Gimenes LU, Ferreira RM, Ayres H, Castro LA, Sales JNS, Baruselli PS. 2010b. Equine chorionic gonadotropin improves the efficacy of a progestin-based fixed-time artificial insemination protocol in Nelore (Bos indicus) heifers. Anim Reprod Sci, 118:182-187.

Sexten AJ. 2011. The effects of hay processing and feeder design on hay utilization. Stillwater, OK: Oklahoma State University. Marter's thesis.

Silkea V, Diskina MG, Kennya DA, Boland MP, Dillon P, Mee JF, Sreenana JM. 2002. Extent, pattern and factors associated with late embryonic loss in dairy cows. Anim Reprod Sci, 71:1-12.

Stewart F, Allen WR. 1981. Biological functions and receptor binding activities of equine chorionic gonadotrophins. J Reprod Fertil, 62:527-536.

Tallam SK, Duffield TF, Leslie KE, Bagg R, Dick P, Vessie G, Walton JS. 2003. Ovarian follicular activity in lactating Holstein cows supplemented with monensin. J Dairy Sci, 86:3498-3507.

Wettemann RP, Lents CA, Ciccioli NH, White FJ, Rubio I. 2003. Nutritional- and suckling-mediated anovulation in beef cows. J Anim Sci, 81(E-suppl):48-59. 